\title{
Impact of Intracoronal Dentin Treatment Prior to Bleaching on Bond Strength of Restorative Materials
}

Dental School, University of Ribeirão

Preto, Ribeirão Preto, SP, Brazil

Correspondence: Profa. Danielle Cristine Messias, Avenida Afonço Valera, 251, 14098-561 Ribeirão Preto, SP, Brasil. Tel: +55-16-3603-6783. e-mail: dcf.messias@gmail.com
Erica Moreno Zanconato-Carvalho, João Felipe Bruniera, Natália Spadini de Faria, Vivian Colucci, Danielle Cristine Messias

\begin{abstract}
Surface treatment of dentin before the bleaching procedure may affect its permeability and influence the bond strength of restorative materials. This study evaluated the influence of surface treatment before the bleaching on shear bond strength (SBT) of restorative materials to intracoronal dentin. Dentin slabs were subjected to surface treatment: no bleaching (control - CON), no surface treatment + bleaching (HP), 37\% phosphoric acid + bleaching (PA) and Er:YAG laser + bleaching (L). After the bleaching procedure, specimens $(n=10)$ were restored with: microhybrid composite resin $(\mathrm{MH})$, flowable composite resin (F), and resin-modified glass-ionomer cement (RMGIC). The shear test was carried out. ANOVA and Tukey's test $(\alpha=0.05)$ showed significant difference for surface treatment and restorative materials $(p<0.05)$. CON presented higher STB and was statistically different from HP $(p<0.05)$. PA and $L$ showed intermediate values and were statistically similar to CON and HP ( $>>0.05)$. STB for MH and F were higher than RMGIC $(p<0.05)$, and did not differ from each other ( $p>0.05$ ). The surface treatments with phosphoric acid and Er:YAG laser before the bleaching procedure provided shear bond strength at the same level of unbleached dentin and the composite resins presented superior bond strength to the intracoronal dentin.
\end{abstract}

Key Words: bleaching, dentin, Er:YAG laser, phosphoric acid, bond strength.

\section{Introduction}

The bleaching of nonvital discolored teeth has been advised for achieving aesthetically desirable appearance (1). Recovery of the chromatic alteration of the dental tissues is reached by penetration of the external and internal bleaching agents through the dentin (2).

When internal bleaching treatment is performed, filling material placed to seal the access cavity must be removed. At this time, smear layer is produced and this may reduce the dentinal diffusion of the bleaching agent inserted in the pulp chamber (3). Acid etching of tooth surfaces and laser treatment have been evaluated to prepare the intracoronal dentin prior to bleaching (4), removing the formed smear layer and exposing the dentinal tubules entrance (5).

Dentin etching with 37\% phosphoric acid promotes dissolution of peritubular dentin, exposes the collagen fibers of the intertubular dentin and opens the dentinal tubules (3). On the other hand, Er:YAG laser irradiation of the dentin makes the surface irregular, with absence or modification of the smear layer and exposed tubules, changing the dentin permeability (6).

Although tooth whitening presents satisfactory cosmetic results, bleaching agents have been associated with undesirable effects in the dental hard tissues, including reduced microhardness (7), changes in modulus of elasticity (8) and dental substrate morphology (7). These aspects could interfere with the adhesion of restorative materials to the tooth bleached surface (9). Additionally, the adhesive strength may also be compromised by residual oxygen remaining within the dentinal tubules, which inhibits the polymerization of restorative materials (8-11).

After bleaching procedure, different restorative materials, such as resin composite and glass-ionomer cements (GICs), may be employed to remake the damaged structure and to seal the access to the pulp chamber in anterior endodontically treated teeth $(7,9)$. Besides the ability to adhere to tooth structure by means of adhesive systems, microhybrid composite resins exhibit satisfactory mechanical properties (12) and the flowable composite resins have greater flow and dissipation of tensions (13). The resin-modified glass-ionomer cements (RMGIC) combine the properties of conventional GICs, such as chemical adhesion to dental tissues and linear thermal expansion coefficient similar to the tooth and the mechanical properties of resins. These characteristics provide the RMGIC intermediate physical properties when compared with GICs and composite resins (14).

Given the divergent protocols for non-vital teeth bleaching, varying pretreatment of the surface and the diversity of restorative materials to restore bleached dentin, it becomes relevant to consider the impact of the surface treatment before the bleaching procedure on bond strength of different restorative materials to the intracoronal dentin.

This study sought to evaluate in vitro the influence of 
the surface treatment of intracoronal dentin with 37\% phosphoric acid and Er:YAG laser prior to bleaching with $38 \%$ hydrogen peroxide on dentin bond strength of three restorative materials: microhybrid composite resin, flowable composite resin and RMGIC. The null hypothesis tested was that the surface treatments of intracoronal dentin before bleaching would not affect the bond strength of restorative materials to dentin.

\section{Material and Methods}

This study was approved by the Ethics Committee of the University of Ribeirão Preto (Protocol \#070/11).

\section{Experimental Design}

The factors under study were surface treatment at four levels (I- no treatment and unbleached, II- no treatment + bleaching with $38 \%$ hydrogen peroxide, III- acid etching with $37 \%$ phosphoric acid + bleaching with $38 \%$ hydrogen peroxide and IV- Er:YAG laser irradiation + bleaching with $38 \%$ hydrogen peroxide) and restorative materials at three levels [a. Microhybrid composite resin (MH), b. Flowable \& composite resin (F) and c. Resin-modified glass-ionomer cement (RMGIC)]. Experimental units were 120 intracoronal human dentin slabs, which were randomly assigned into 12 groups $(n=10)$. The response variable was shear bond strength in $\mathrm{MPa}$.

\section{Selection and Preparation of Dental Slabs}

Sixty sound human permanent maxillary canines, stored in thymol $(0.1 \%)$ at $9{ }^{\circ} \mathrm{C}$ were selected and examined on stereomicroscopy (Leica Microsystems, Wetzlar, Germany) under 20x magnification to discard those with fractures or cracks in the crown.

Teeth were sectioned on cementoenamel junction with a diamond saw (KG Sorensen, Barueri, SP, Brazil) on a lowspeed handpiece (Dabi Atlante, Ribeirão Preto, SP, Brazil). Dental crowns were sectioned in mesiodistal direction, and then each slab was again sectioned on incisal, mesial, distal and cervical surfaces. From each crown, two quadrangular dentin slabs measuring $5 \times 5 \mathrm{~mm}$ were obtained, totaling
120 dental specimens.

The sections were individually embedded in polyester resin (JET; Clássico, São Paulo, SP, Brazil) using polyvinyl chloride (PVC) cylinders $(1.5 \mathrm{~cm}$ diameter and $1.5 \mathrm{~cm}$ high), with the dentin surfaces facing upwards. After polymerization, PVC cylinders were removed and specimens were ground under water irrigation using 400- and 600-grit $\mathrm{SiC}$ paper. Finishing was accomplished with 1200 -grit SiC paper for 60 cycles to standardize the surface smoothness. After polishing, specimens were washed with $10 \mathrm{~mL}$ of $1 \%$ sodium hypochlorite for $10 \mathrm{~min}$, to simulate the irrigation during biomechanical preparation of radicular canal.

\section{Surface Treatment}

The specimens were randomly assigned and subjected to one of the four following surface treatments: I- no treatment and unbleached, II- no treatment + bleaching with 38\% hydrogen peroxide, III- acid etching with 37\% phosphoric acid + bleaching with 38\% hydrogen peroxide and IV- Er:YAG laser irradiation + bleaching with 38\% hydrogen peroxide. A brief description of the surface treatment applied in each group is presented in Table 1.

For acid etching with 37\% phosphoric acid (Super Etch; 3M ESPE, St. Paul, MN, USA), the product was applied on dentin surface for $30 \mathrm{~s}$, rinsed with water and dried with absorbing paper.

For surface irradiation, the Er:YAG laser (Opus 20; OpusDent Ltd., Tel-Aviv, Israel) used at a 2,940 nm wavelength, $200 \mathrm{~mJ}$, frequency of $10 \mathrm{~Hz}$, an energy density of $3.5 \mathrm{~J} / \mathrm{cm}^{2}$ and spot diameter of $1.0 \mathrm{~mm}$. The laser beam was delivered under constant water cooling in non-contact and focused mode (at a 12-mm standardized distance), using an automatic custom-designed apparatus. The specimens were placed in a semi-adjustable base which was automatically moved in both right-to-left and forwardto-back directions. Each specimen was irradiated during approximately $10 \mathrm{~s}$.

Specimens from negative control group (no treatment plus no bleaching) were kept in relative humidity at 37 ${ }^{\circ} \mathrm{C}$. For bleaching, the specimens were exposed to $38 \%$

Table 1. Description of the surface treatments applied in each group

\begin{tabular}{|c|c|}
\hline Surface treatment & Description \\
\hline No treatment + no bleaching & Storage in relative humidity at $37^{\circ} \mathrm{C}$. \\
\hline No treatment + bleaching & $\begin{array}{l}\text { Bleaching with } 38 \% \text { hydrogen peroxide performed in a session with three } \\
\text { applications of } 10 \mathrm{~min} \text { and intervals of } 5 \mathrm{~min} \text { between each one. }\end{array}$ \\
\hline Acid etching + bleaching & $\begin{array}{l}\text { Etching with } 37 \% \text { phosphoric acid for } 30 \mathrm{~s} \text { followed by rinsing and drying. Bleaching with } 38 \% \text { hydrogen } \\
\text { peroxide performed in a session with three applications of } 10 \text { min and intervals of } 5 \text { min between each one. }\end{array}$ \\
\hline Laser irradiation + bleaching & $\begin{array}{l}\text { Er:YAG laser irradiation }(200 \mathrm{~mJ} / 10 \mathrm{~Hz} \text { ) for } 10 \mathrm{~s} \text {. Bleaching with } 38 \% \text { hydrogen peroxide performed } \\
\text { in a session with three applications of } 10 \mathrm{~min} \text { and intervals of } 5 \text { min between each one. }\end{array}$ \\
\hline
\end{tabular}


hydrogen peroxide (Opalescence X-tra Boost; Ultradent Products, Inc., South Jordan, UT, USA) in gel form, which was mixed with red dye at the moment of use, according to the manufacturer's instruction. A session of bleaching was performed applying a thin layer of gel (2-mm thick) on dentin surface for $10 \mathrm{~min}$. This procedure was repeated three times during the session, with 5 min waiting time between each application.

All specimens were sealed with cotton ball and provisional restorative material (Coltosol; Vigodent AS Ind. Com., Rio de Janeiro, RJ, Brazil). Slabs were stored in relative humidity with artificial saliva at $37^{\circ} \mathrm{C}$ for 10 days (15).

\section{Specimen Restoration}

The samples were restored with the chosen materials for each experimental group $(n=10)$ : microhybrid composite resin (Filtek Z250, 3M ESPE), flowable composite resin (FilteK Z350 Flow, 3M ESPE) and RMGIC (Vitremer, 3M ESPE).

Specimens were restored using a split polytetrafluoroethylene mold $(3 \mathrm{~mm}$ inner diameter, 4 $\mathrm{mm}$ high) stabilized with vinyl polysiloxane (Perfil Denso; Vigodent), in order to obtain restorative material cylinders with the above described measurements.

On specimens restored with composite resin, the surface was etched with $37 \%$ phosphoric acid for $15 \mathrm{~s}$, washed with distilled water during $15 \mathrm{~s}$ and dried with absorbing paper. Two layers of Single Bond adhesive (3M, ESPE) were applied, followed by an air spray, and then light-cured for $10 \mathrm{~s}$ (1500 mW/cm², Raddi Plus, SDI Ltd, Victoria, Australia) according to the manufacturer's instructions.

For groups restored with microhybrid and flowable composite resin, the material was inserted in 3 increments, light-activated by LED for $20 \mathrm{~s}$ at each increment, maintaining the end of the optic fiber $10 \mathrm{~cm}$ from the resin surface using a device developed for this purpose.

The RMGIC was prepared incorporating all powder in liquid (1:1; powder/liquid), inserted in a single increment with Centrix syringe (DFL Ind. SA, Rio de Janeiro, RJ, Brazil) and light-activated for $40 \mathrm{~s}$, as recommended by the manufacturer. After removing the split teflon mold,

Table 2. Shear bond strength of restorative materials to dentin subjected to different surface treatment

\begin{tabular}{lc}
\hline Surface Treatment & Means \pm SD $(\mathrm{MPa})$ \\
\hline No treatment/unbleached & $3.40 \pm 1.06 \mathrm{a}$ \\
No treatment/bleaching & $2.17 \pm 0.92 \mathrm{~b}$ \\
Phosphoric acid/bleaching & $2.76 \pm 0.80 \mathrm{ab}$ \\
Laser/bleaching & $2.77 \pm 0.93 \mathrm{ab}$ \\
\hline
\end{tabular}

Different letters indicates statistically significant difference $(p<0.05)$. all restored specimens were stored in relative humidity at $37{ }^{\circ} \mathrm{C}$ during $24 \mathrm{~h}$.

\section{Shear Bond Strength Test}

The specimens were subjected to shear bond test in a universal testing machine (Instron 4444; Instron Corporation, Canton, MA, USA) at a $0.5 \mathrm{~mm} / \mathrm{min}$ crosshead speed and a $2 \mathrm{kN}$ load cell until the restoration displacement. Shear bond strength values were registered in $\mathrm{kN}$ and transformed into MPa.

Failure modes at the resin/dentin interface were analyzed under a stereoscopic microscope at 40x magnification (Leica Microsystems), and displayed in percent. Failure was considered adhesive if it occurred at the dentin/adhesive interface, cohesive if it occurred in the material or the substrate and mixed if it involved both the interface and the material.

\section{Statistical Analysis}

After checking homoscedasticity (Levene's test) and normality (Kolmogorov-Smirnov's test), two-way ANOVA and Tukey's test were used. The statistical analysis was performed with the 17 SPSS software (SPSS Inc., Chicago, IL, USA) at a $5 \%$ significance level.

\section{Results}

Two-way ANOVA showed statistically significant difference for the factor surface treatment $(p=0.000)$ and restorative material $(p=0.001)$.

The specimens without surface treatment and unbleached showed higher bond strength than those without surface treatment and bleached $(p<0.05)$, which had the lowest mean bond strength. The acid-etched and bleached specimens and those irradiated with Er:YAG laser before bleaching showed intermediate values, sometimes similar to the control group ( $p>0.05$ ) and sometimes to the group without surface treatment and bleached ( $p>0.05)$ (Table 2).

The microhybrid and flowable composite resins provided higher bond strength values, similar between them ( $p>0.05)$ and different from the RMGIC $(p<0.05)$ (Table 3$)$.

In the failure analysis, adhesive failures prevailed in all groups, except for the untreated group restored with

Table 3. Bond strength of restorative materials to intracoronal dentin

\begin{tabular}{lc}
\hline Restorative Material & Means \pm SD (MPa) \\
\hline Microhybrid composite resin & $3.12 \pm 1.36$ a \\
Flowable composite resin & $3.44 \pm 1.90$ a \\
Resin-modified glass-ionomer cement & $1.77 \pm 0.75$ b \\
\hline
\end{tabular}

*Similar letters indicate statistical difference $(\mathrm{p}<0.05)$. 
flowable composite resin, which presented higher amount of cohesive failures within the substrate. The percentage of failures is displayed in Figure 1.

\section{Discussion}

The null hypothesis tested in this study, that there would be no significant difference in bond strength of restorative materials to dentin whether prior to bleaching exposes or not the surface to treatments, was rejected.

In the current study, the bond strength of specimens without surface treatment and without bleaching was greater than specimens without surface treatment and bleaching. This fact may be attributed to the mechanism of action of the bleaching agent on the dentin, with presence of the $\mathrm{OH}$ - radical (16) in the dentin (1). The $\mathrm{OH}$ - radical is a strong oxidizing agent that has high penetrating power, acts in intertubular and peritubular dentin by degradation of the organic portion, breaking the polypeptide chain by the destruction of amino-acids of the matrix (16). The presence of residual oxygen on the dentin surface may impair the penetration of resin into dentin tubules, creating an adhesive interface more susceptible to fracture (17). This fact may explain the prevalence of the adhesive failures in all bleached specimens, regardless of the restorative material.

In this study, there was an interval of 10 days (15) between bleaching procedure and restoration in order to minimize the effect of residual oxygen in dentin tubules. However, to simulate the clinical situation, the surface was sealed with temporary cement that could compromise complete release of the oxygen from the dentin. The oxygen in the tubules inhibits the polymerization of the adhesive system and the resin composite, hence it reduces the strength of the interface between the dentin and restorative material $(9,15)$.

When the dentin was subjected to acid etching or
Er: YAG irradiation prior to bleaching, the bond strength was similar to untreated and unbleached specimens. The surface treatment with phosphoric acid promotes dentin demineralization, exposes collagen fibers, intensifies the infiltration of resin monomers, increasing the adhesion (3). The Er:YAG laser modifies the smear layer, promotes dentinal tubules' opening (total or partial) and produces an irregular surface (6). This ultrastructural aspect favors the adhesion of restorative materials, as previously reported $(18,19)$.

Regarding restorative materials, microhybrid and flowable composite resins demonstrated higher bond strength when compared with RMGICs. The adhesion process of GICs is by chemical bonding between the carboxylic polyacids from material, which are chelating agents, and calcium ions from tooth (20). Nevertheless, GIC's bond strength is considered low, since chemical adhesion is lower than mechanical adhesion to tooth structure (21) by means of the hybrid layer, as occurs in resin materials. Although RMGIC presents chemical and also micromechanical adhesion to dentin structure (22), it is speculated that the mechanical component is lower than the one found in the composites, and this aspect seems to be insufficient to provide similar adhesion among them (21). Another aspect that may have contributed to the lower bond strength of the RMGIC is the possible presence of bubbles, which is very frequent (20). Bubbles along the interface between dentine and RMGIC allow an uneven stress concentration that may lead to failure in adhesion (21).

Composite resins adhere to dental substrate by mechanical imbrication within the tubules as well penetration of resin material inside the intertubular dentin collagen matrix (23). This mechanism explains the superior adhesion of microhybrid and flowable composite resins to intracoronal dentin, as demonstrated in the present study.

Despite the differences in composition and properties

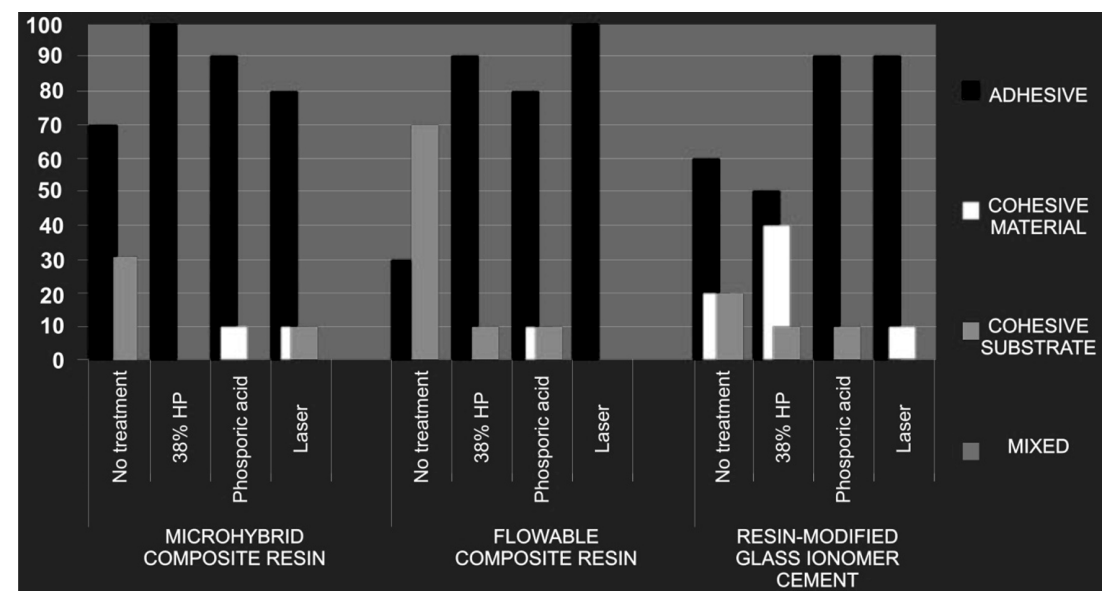

Figure 1. Failure modes observed in each group after the shear test (\%). 
of resins, both have characteristics that favor the adhesion process. The flowable composite resin presents reduced content of fillers and viscosity, with a high runoff (24), which contributes to its infiltration into dentin. The microhybrid composite resin used in this study has a high amount of crosslinking in chemical structure that increases the modulus of elasticity and enhances the mechanical strength (12). For both composite resins, polymerization shrinkage in the adhesive interface was reduced by the incremental restoration technique.

Within the limitations of an in vitro study, it may be concluded that the surface treatment with $37 \%$ phosphoric acid or Er:YAG laser irradiation before the intracoronal bleaching provides similar bond strength to unbleached dentin. The microhybrid and flowable resins had superior adhesion to dentin than the RMGIC. Even though both etching with 37\% phosphoric acid and Er:YAG laser irradiation have been efficient to increase bond strength to bleached dentin, it is necessary to consider that increased dentin permeability may enhance the risk of adverse effects (25). Further researches are needed to confirm the obtained results, as well as to indicate or to contraindicate the surface treatment before a bleaching procedure.

\section{Resumo}

0 tratamento superficial da dentina previamente ao clareamento pode afetar a sua permeabilidade e influenciar a resistência de união de materiais restaurados. Este estudo avaliou a influência do tratamento superficial antes do clareamento na resistência ao cisalhamento (RC) de materiais restauradores à dentina intracoronária. Fragmentos de dentina foram submetidos ao tratamento de superfície: não clareadas (controle - CON), sem tratamento de superficie + clareamento (HP), ácido fosfórico 37\% + clareamento (AF), e laser Er:YAG + clareamento (L). Após o procedimento clareador, os espécimes foram restaurados com $(n=10)$ : resina composta micro-híbrida $(\mathrm{MH})$, resina composta fluida (F), e cimento de ionômero de vidro modificado por resina (CIVMR). 0 teste de cisalhamento foi realizado. ANOVA e teste de Tukey $(\alpha=0,05)$ mostraram diferença significante para tratamento superficial e material restaurador $(p<0,05)$. 0 grupo controle apresentou maior resistência de união e foi estatisticamente diferente de HP $(p<0,05)$. AF e $L$ mostraram valores intermediários e foram similares ao $\operatorname{CON}$ e HP $(p>0,05)$. A resistência de união para $\mathrm{MH}$ e $\mathrm{F}$ foi maior que $\operatorname{CIVMR}(p<0,05)$, e não diferiram entre si $(p>0,05)$. 0 tratamento da superfície dentinária com ácido fosfórico e laser Er:YAG previamente ao clareamento promoveu resistência de união ao nivel da dentina não clareada e a adesão à dentina intracoronária foi superior com as resinas compostas.

\section{References}

1. Plotino G, Buono L, Grande NM, Pameijer CH, Somma F. Nonvital tooth bleaching: A review of the literature and clinical procedures. J Endod 2008;34:394-407.

2. Palo RM, Bonetti-Filho I, Valera MC, Camargo CH, Camargo S, MouraNetto C. Quantification of peroxide ion passage in dentin, enamel, and cementum after internal bleaching with hydrogen peroxide. Oper Dent 2012;37:660-664.

3. Camps J, Pommel L, Aubut V, About I. Influence of acid etching on hydrogen peroxide diffusion through human dentin. Am J Dent 2010;23:168-170.

4. Mohammadi N, Kimyai $S$, Navimipour EJ, Soleimanzadeh R, Bonab SS. Effect of acid etching and laser treatment of dentin surface on intracoronal bleaching efficacy. Photomed Laser Surg 2010;28:551-555.

5. Pashley DH, Carvalho RM. Dentine permeability and dentine adhesion. J Dent 1997;25:355-372.

6. Colucci V, Amaral FL, Pécora JD, Palma-Dibb RG, Corona SA. Effects of water flow on ablation rate and morphological changes in human enamel and dentin after Er:YAG laser irradiation. Am J Dent 2012;25:332-336.

7. Varanda $E$, Prado $M$, Simão RA, Dias KR. Effect of in-office bleaching agents on the surface roughness and morphology of different dental composites: An AFM study. Microsc Res Tech 2013;76:481-485.

8. Chng HK, Ramli HN, Yap AUJ, Lim CT. Effect of hydrogen peroxide on intertubular dentine. J Dent 2005;33:363-369.

9. Shinohara MS, Peris AR, Pimenta LA, Ambrosano GM. Shear bond strength evaluation of composite resin on enamel and dentin after nonvital bleaching. J Esthet Restor Dent 2005;17:22-29.

10. Barcellos DC, Benitti P, Fernandes W, Valera MC. Effect of carbamide peroxide bleaching gel concentration on the bond strength of dental substrates and resin composite. Oper Dent 2010;35:463-469.

11. Ferrari R, Attin T, Wegehaupt FJ, Stawarczyk B, Tauböck $\Pi$. The effects of internal tooth bleaching regimens on composite-to-composite bond strength. J Am Dent Assoc 2012;143:1324-1331.

12. Melo MP, Valle AL, Pereira JR, Bonachela WC, Pegoraro LF, Bonfante G. Evaluation of fracture resistance of endodontically treated teeth restored with prefabricated posts and composites with varying quantities of remaining coronal tooth structure. J Appl Oral Sci 2005;13:141-146.

13. Beun S, Bailly C, Devaux J, Leloup G. Rheological properties of flowable resin composites and pit and fissure sealants. Dent Mater 2008;24:548555.

14. Pereira LC, Nunes MC, Dibb RG, Powers JM, Roulet JF, Navarro MF. Mechanical properties and bond strength of glass-ionomer cements. J Adhes Dent 2002;4:73-80.

15. Souza-Gabriel AE, Vitussi LO, Milani C, Alfredo E, Messias DC, SilvaSousa YT. Effect of bleaching protocols with 38\% hydrogen peroxide and post-bleaching times on dentin bond strength. Braz Dent J 2011;22:317-321.

16. Kawamoto K, Tsujimoto Y. Effects of the hydroxyl radical and hydrogen peroxide on tooth bleaching. J Endod 2004;30:45-50.

17. Curylofo FA, Messias DC, Silva-Sousa YT, Souza-Gabriel AE. Bond strength of restorative material to dentin submitted to bleaching and Er:YAG laser post-treatment. Photomed Laser Surg 2014;32:495-499.

18. Capa N, Aykor A, Ozel E, Calikkocaoglu S, Soyman M. Effect of Er:YAG laser irradiations on shear bond strength of three self-adhesive resin cements to dentin. Photomed Laser Surg 2010;28:809-821.

19. Samad-Zadeh A, Harsono M, Belikov A, Shatilova KV, Skripnik A, Stark $P_{1}$ et al.. The influence of laser-textured dentinal surface on bond strength. Dent Mater 2011;27:1033-1044.

20. Burrow MF, Nopnakeepong U, Phrukkanon S. A comparison of microtensile bond strengths of several dentin bonding systems to primary and permanent dentin. Dent Mater 2002;18:239-245.

21. Bonifácio CC, Shimaoka AM, De Andrade AP, Raggio DP, van Amerongen WE, de Carvalho RC. Micro-mechanical bond strength tests for the assessment of the adhesion of GIC to dentine. Acta Odontol Scand 2012;70:555-563.

22. Pereira PN, Yamada T, Tei R, Tagami J. Bond strength and interface micromorphology of an improved resin-modified glass ionomer cement. Am J Dent 1997;10:128-132.

23. Tay FR, Hashimoto M, Pashley DH, Peters MC, Lai SC, Yiu CK, et al.. Aging affects two models of nanoleakage expression in bonded dentin. J Dent Res 2003;82:537-541.

24. Attar N, Tam LE, Mccomb D. Flow, strength, stiffness and radiopacity of flowable resin composites. J Can Dent Assoc 2003;69:516-521.

25. Discacciati JA, de Souza EL, Costa SC, Sander HH, Barros V de $M$, Vasconcellos WA. Invasive cervical resorption: etiology, diagnosis, classification and treatment. J Contemp Dent Pract 2012;1:723-728.

Received August 12, 2014 Accepted November 14, 2014 